\title{
Cost and Return of Selling Processed Sunflower Versus Unprocessed Sunflower by Smallholder Farmers in Dodoma Region, Tanzania
}

\author{
William George \\ Department of Economics, University of Dodoma, Dodoma, Tanzania
}

\section{Email address:}

wgeorgelumwaga@gmail.com

\section{To cite this article:}

William George. Cost and Return of Selling Processed Sunflower Versus Unprocessed Sunflower by Smallholder Farmers in Dodoma Region, Tanzania. International Journal of Agricultural Economics. Vol. 5, No. 5, 2020, pp. 181-186. doi: 10.11648/j.ijae.20200505.15

Received: August 11, 2020; Accepted: August 22, 2020; Published: September 24, 2020

\begin{abstract}
This research assessed the motivation of farmers to sell sunflower oil and in seed form and its effects on profitability. Data was collected through survey of 194 smallholder farmers in Dodoma region. The gross margin model was used to analyze profitability and was compared using the difference of mean test between households that sell oil and those who sell in seed form. Tobit Regression Model was used to analyze the factors that affect the proportion of sunflower sold as seeds. Results show that, higher variable costs were observed to farmers who processing sunflower; but higher gross margins were observed to farmers who process sunflower. This implied that farmers selling sunflower oil are more profitable than those farmers selling in seed form. Sunflower oil price, amount of sunflower harvested, size of household, farmer groups have significant and positive relationships with the proportion of sunflower sold as seed. The distance to the nearest machine is negatively and significantly associated with the proportion of sunflower sold as seed. Farmers should be encouraged to process sunflower before sale through training and extension. Access to yield-enhancing inputs, marketing or processing in groups, private entrepreneurs set up processing plants closer to farmers, invest mobile processing through improvement of the rural road network are some interventions proposed in this study to help farmers reduce transactions costs of processing.
\end{abstract}

Keywords: Smallholder Farmers, Processing, Sunflower, Profitability, Markets, Livelihoods

\section{Introduction}

Tanzania ranks second in Africa and $10^{\text {th }}$ in the world in terms of sunflower production [1]. The world share in sunflower seed production stands at $2.4 \%$ and has increased nine-fold from 135000 to 1083000 metric tones in 2000 and 2015 respectively [2]. However, production, processing and marketing of the crop is very low in Tanzania. The reasons for these are dependence on rain-fed agriculture, poor mechanization for cultivation using hand-hoe, small-size of most processors, unbranded and low quality products. The crop is cultivated by 250,000 households who are smallholder farmers owning an average of 0.4 to 2 ha with a few medium and large scale farmers cultivating over 405 ha [3-4]. More than $80 \%$ of these smallholder farmers are located in Dodoma, Manyara, Singida and Morogoro (Eastern and Central corridor) and Kigoma, Iringa and Mbeya in the Southern highland region.
Record is a popularly seed type grown by smallholder farmers in Tanzania which was introduced by Agricultural Research Institute-Ilonga in the country. These seed cultivars can be grown in the drier regions, up to $2000 \mathrm{~m}$ altitude, but they are unsuitable for humid climates. Temperatures for optimum growth are $23-27^{\circ} \mathrm{C}$ and yield of one two tones per hectare [5]. Ninety nine percent of sunflower oil is contained in the seed and two percent is contained in the hull [6]. Record is a sunflower variety with more than $40 \%$ oil content and low hull fraction which range from $20 \%$ to $25 \%$. Sunflower crushers prefer sunflower varieties with seeds which produce high volume of marketable oil compared to cake [7].

Sunflower production in Tanzania has increased by $218 \%$ in 2015 compared to the production of the crop in 2005 [1]. The increase in production of sunflower was attributed to the government and development stakeholder's interventions including the Rural Livelihood Development Program 
(RLDP), Techno-Serve and Netherland Development organization (SNV). The interventions stimulated sunflower production and productivity by enabling smallholders to access quality sunflower seeds, credits and field trainings [3, 8-9]. It increased sunflower processors economies of concentration and markets of products. Also interventions by RLDP and SNV intended to increase sunflower processors capacity to meet Tanzania Food and Drug Authority (TFDA) standards, access loans, and thus offer an opportunity for further growth and expansion of the sunflower firms [3].

Some farmers in Tanzania are still sell sunflower in unprocessed in form as seed despite the notable improvements in farmers' access to processing services [5]. Available research on sunflower have mainly focused on analyzing profit inefficiency in sunflower production [9], sunflower contract farming schemes [3], impact of improved sunflower varieties on income and poverty [8] but with limited attention to sunflower processing to stimulate industrial development in the country. The extent to which sunflower farmers' process sunflower before marketing and how this affects their returns (profits) is unknown particularly in sunflower subsector in Tanzania. Analyzing the returns from selling processed and unprocessed sunflower is particularly informative, since the profitability of processing (or lack of it) could explain why some farmers sell processed sunflower (oil) and others don't despite the evidence of increased availability of processing machines in Tanzania.

To this effect, the research is therefore made to provide answers to the research question: is sunflower processing profitable? Thus, the specific objectives of the study were to: (i) study the profitability of selling processed versus unprocessed sunflower among sunflower-growing households and (ii) identify the factors that affects the proportion of sunflower sold in processed form.

\section{Materials and Methods}

\subsection{Study Area}

The study was conducted in Kongwa district and Dodoma rural district. The two districts were purposively selected because various interventions have been implemented by the government of Tanzania and other development stakeholders.

\subsection{Research Design}

A non-experimental research design was used in this study. Since the nature of the proposed study requires gathering and analysis of vast data from households, the study will employ a cross-sectional design, which allows collection of large amount of data at one point in time.

\subsection{Population}

A target population is the population to which the researcher ultimately wants to generate the results [10]. The target population for this study was all sunflower smallholder farmers of Kongwa and Dodoma rural districts whose land, location or climate allow them to produce sunflower seeds.

\subsection{Sampling Procedures}

The sampling frame to conduct this study constituted farmers in Kongwa and Dodoma rural districts. The sampling to conduct the study on the part of farmers is the farmers growing and selling sunflower. Based on the report of the National Sample Census of Agriculture in 2012 there are about a total of 120000 growing households engaged in sunflower production. Due to financial and time resource constraints to contact each household growing sunflower, sampling approach will be used. The sample is calculated using the formula recommended by Yamane (1973) and used by other researchers [11]. The Equation is presented below:

$$
n=\frac{N}{1+N e^{2}}
$$

Where, $\mathrm{n}$ is sample, $\mathrm{N}$ is population, $\mathrm{e}^{2}$ is probability of error.

With $\mathrm{N}=120000, \mathrm{e}=5 \%$ (95 percent confidence).

The sample size is calculated according to the recommendation as follow:

$$
n=\frac{120,000}{1+120,000 *(0.05)^{2}}=\sim 300.0025
$$

Hence the sample size for farmers (growers) was 300 households. In each of the two districts, 150 households were selected for interview. About 106 did not harvest the crop during the seasons of study due to drought conditions and thus 194 respondents were interviewed. The entry point for the study will be at ward level in the target districts. In consultation with the district officials purposive sampling was used to identify districts to be included in the study. In collaboration with extension officers within each district, the villages that is significant for sunflower production was identified and selected for the study. A combination of purposive, systematic, snowball and simple random sampling techniques were employed to select participants for the study. Under snowball method, researcher knows a few people engaged in sunflower processing and approached them and eventually they connected the researcher with other processors whom they know.

A survey was conducted in October 2017 to collect data using structured questionnaire. Focus Group Discussions (FGDS) were conducted to 5-10 people (2 FGDs per district). This method were used to validate and compare the information collected using other methods and to get group opinions (collective view of the participants on what they do and don't like about the existing) compared to individuals responses. A number of meetings, informal interactions and interviews were conducted. Field visits were carried out to the major sunflower producing areas.

The secondary data supplement the primary methods and provided the researcher with an opportunity to gain more information about the phenomenon. The secondary information was collected from various sources including: District Agriculture and Livestock Development Offices; Ilonga Agricultural Research Institutes (ARIs) with mandate in oil seeds research in Tanzania and different sunflower project documents. 


\subsection{Data Analysis}

The first specific objective was estimated using Gross Margin Analysis (GMA). It was used to estimate the profitability of selling processed sunflower (oil) and unprocessed sunflower (seeds). The GMA was used over other methods because; (a) the study focuses on an annual crop with a three to four month-long cropping season (i.e., short-run), and GMA is an appropriate measure of profits for short-run planning decisions, (b) it is convenient since it provides a measure of returns to variable costs and not fixed costs. Comparison of profits from selling oil versus seeds was achieved through a two-step procedure. In the first step, the profitability of selling sunflower in different forms (oil and seeds) was estimated using GMA. Following [12], the GMA was calculated Equation 1:

$$
G M A_{i}=T R_{i}-T V C_{i}
$$

Where:

$G M A_{i}=$ Gross Margin for household $i$,

$T R_{i}=$ Total Revenue received by household $i$,

$T V C_{i}=$ Total Variable Cost incurred by household.

The total revenue was computed using the prices at which households sold either in oil or seed form and the amount sold either in seed or processed. The gross margins in each form was subjected to the test of difference of means to determine if there is a significant difference (second step).

The second specific objective was analyzed using the Tobit Regression Model. The regression was used to establish the factors influencing the proportion of sunflower sold after processing. The model is specified as presented in Equation 2.

$$
y_{i}=\alpha_{0}+\alpha_{1} X_{1}+\alpha_{2} X_{2}+\alpha_{3} X_{3}+\alpha_{4} X_{4}+\alpha_{5} X_{5}+\alpha_{6} X_{6}+\alpha_{7} X_{7}+\alpha_{8} X_{8}+\varepsilon_{i}
$$

Where:

$y_{i}=$ Dependent variable (proportion of sunflower sold as seed),

$\alpha 0=$ the intercept term,

$X 1=$ Experience in growing sunflower,

$X 2$ = Education level of household head,

$X 3=$ Household size,

$X 4=$ Price at which processed sunflower was sold,

$X 5=$ Distance to nearest sunflower processing machines,

$X 6=$ Membership to sunflower farmers groups,

$X 7$ = Sunflower output,

$X 8=$ Proportion of household income from other sources,

$\alpha 1-\alpha 8=$ parameters to be estimated in the model,

$\varepsilon i=$ Stochastic error term.

\section{Results and Discussion}

\subsection{Profitability of Selling Processed Sunflower (Oil) and Unprocessed Sunflower (Seeds)}

The variable costs of production and marketing of sunflower by farmers in the study area is summarized in Table 1. It was found that the average labor costs was higher at TZS 184324 per/acre than the costs sunflower seeds at (TZS 10568 per/acre), transportation was (TZS 6 590) and postharvest handling management was (TZS 17 517) used by the respondents. This finding is in line with other studies which noted that labor is the most significant cost item in sunflower production [13, 14].

\begin{tabular}{|c|c|c|c|c|}
\hline \multirow{2}{*}{ Variables } & \multicolumn{4}{|l|}{ Average value } \\
\hline & Entire sample size $(N=194)$ & “Unprocessed" $(\mathrm{N}=33)$ & "processed" $(\mathrm{N}=94)$ & "Both" $(N=67)$ \\
\hline \multicolumn{5}{|l|}{ A: Revenues } \\
\hline Sunflower sales (kg/acre) & $772.99(689.94)$ & $668.74(885.29)$ & $859.69(619.27)$ & $702.69(671.16)$ \\
\hline Price $(\mathrm{TZS} / \mathrm{kg}))$ & & $900.30^{\mathrm{a}}(195.42)$ & $1,437.77^{\mathrm{b}}(312.87)$ & \\
\hline Total Revenue/acre & $96,6056.7(811,797)$ & $590,170^{\mathrm{a}}(800,877.5)$ & $1,197,713^{\mathrm{b}}(783,756.7)$ & $826,185^{\mathrm{a}}(763955.2)$ \\
\hline \multicolumn{5}{|l|}{ B: Costs of Operations } \\
\hline Costs of seeds $\left(\right.$ TZSacre $\left.^{-1}\right)$ & $10568.14(13,343.73)$ & $7,700.56(7,563.14)$ & $15,138.36(16,416.77)$ & $5,568.57(7,344.68)$ \\
\hline Post-harvest handling (TZS) & $17,516.81(23,201.81)$ & $9,818.18(17,821.08)$ & $22,413.12(26,155.79)$ & $14,439.23(19,565.73)$ \\
\hline Transport cost (TZS) & $6,590.72(10,829.1)$ & $2,166.67^{\mathrm{a}}(5,572.907)$ & $7,928.72 b(10,070.88)$ & $6,892.54^{\mathrm{b}}(13,134.83)$ \\
\hline Processing cost (TZS/kg) & & & $168.32(17.91)$ & \\
\hline \multicolumn{5}{|l|}{ C: Labour Cost } \\
\hline Field clearing (TZS/acre) & $51,389.2(58,499.32)$ & $33,527.02(55,604.35)$ & $65,012.73(67,015.66)$ & $41,073.37(40,594.53)$ \\
\hline Land cultivation (TZS/acre) & $12,228.07(8,888.29)$ & $7,584.74(8,932.73)$ & $15,397.87(8,929.83)$ & $10,067.91(7,081.05)$ \\
\hline Sowing (TZS/acre) & $22,549.27(19,659.78)$ & $13,251.52(17,070.99)$ & $29,601.06(21,298.52)$ & $17,235.5(14,388.5)$ \\
\hline Chemical application /acre & $7,523.58(13,715.24)$ & $4,415.59(13,392.21)$ & $10,599.57(15,742.26)$ & $4,738.81(9,366.83)$ \\
\hline Weeding (TZS/acre) & $35,455.15(38,871.81)$ & $19,818.18(26,198.41)$ & $45,882.98(45,244.11)$ & $28,526.87(29,588.77)$ \\
\hline Bird scaring (TZS/acre) & $28,537.8(20,279.4)$ & $17,676.77(17,661.6)$ & $34,207.45(20,048.65)$ & $25,932.84(19,321.82)$ \\
\hline Harvesting (TZS/acre) & $26,641.24(31,522.07)$ & $16,630.3(30,479)$ & $34,574.47(34,622.77)$ & $20,441.79(24,235.27)$ \\
\hline Total & $184,324.3(174,039)$ & $112,904.1^{\mathrm{a}}(157,323.6)$ & $235,276.1^{\mathrm{b}}(193,713.3)$ & $148,016.8^{\mathrm{a}}(126,931.9)$ \\
\hline D: Total Variable Costs & 219,000 & $132,589.5^{\mathrm{a}}$ & $280,756.3^{\mathrm{b}}$ & $174,917.1^{\mathrm{a}}$ \\
\hline TVC/acre $=\mathrm{B}+\mathrm{C}$ & $(199,279.8)$ & $(174,032.7)$ & $(220,495.2)$ & $(147,643.6)$ \\
\hline E: Gross Margin GM/acre = A-D & $747,056.7(648,787.9)$ & $457,580.5^{\mathrm{a}}(644,861.1)$ & $916,956.3^{\mathrm{b}}(616,837.2)$ & $651,267.9^{\mathrm{a}}(633,087.3)$ \\
\hline
\end{tabular}

Table 1. Sunflower Revenue and Costs of Production and Marketing.

1) Pair-wise t-test with equal variances assumed.

2) ab, ba shows that the variables are statistically different between the categories.

3) aa, bb shows that the variables are not significantly different between the categories.

4) Standard deviations are in brackets. 
The costs of labour for the respondents who process sunflower before sale was significantly higher at TZS 235276 per/acre and sunflower seeds at TZS 15138 per/acre than respondents who sold sunflower in seed form. The mean costs of transportation for respondents who sold sunflower as seed was TZS 2167 which is significantly lower than for the respondents who sold all sunflower at TZS 7929 or part at TZS 6893 of their sunflower in processed form. This is because the former mostly sell their sunflower at the farmgate and therefore avoid costs of transportation. Respondents who sold sunflower in seed form also avoid processing charges at an average of TZS 168.32 per/kilogram. However, the price in kilogram of the of processed sunflower was at TZS 1438 which was significantly higher than the price of sunflower seed at (TZS 900); which offset the higher costs of labor, seed, transportation milling and postharvest handling used by the respondents that process all their sunflower before sale to make sunflower processing profitable.

The gross margins were positive for sunflower sold in both processed and seed form. This suggests that sunflower production is a profitable venture in the study area. The results conform with of [14-17]. It was noted in this study although respondents who process sunflower before sale used significantly higher costs at TZS 280756 per/acre than who sell all at TZS 132590 per/acre or part at TZS 174917 per/acre) of their sunflower as seed, they receive higher gross margins or profits at TZS 916956 per/acre from sunflower sales than respondents who sell all at TZS
457581 per/acre or part at TZS 651268 per/acre of their sunflower as seed. It suggests that the higher price of sunflower oil relative to seed more than offsets the higher costs used by respondents who sold processed sunflower to make the selling of processed sunflower more profitable than selling in seed form [18].

\subsection{Factors Affecting the Proportion of Sunflower Sold as Seeds}

Table 2 show that output of sunflower, size of household, price of oil, distance to nearest sunflower processing machines and membership in sunflower farmers' groups significantly affect the proportion of sunflower sold as seeds. The price of processed sunflower (oil) had a positive effect on the proportion of sunflower sold as seeds at one percent significance level. This implies that as the price of processed sunflower rises, it triggers increasing proportions of sunflower to be sold as seeds. This concurs with the findings of studies that prices being one of the key determinants of the proportion of output sold because of their effect on the profitability of commodity production and marketing $[15,19$ 22]. The volume of sunflower harvested by the household is also positively and significantly associated with the proportion of sunflower sold as seeds. This is because the fixed transaction costs of processing can be spread over a larger volume of produce, making it cheaper to invest in processing before sale [23].

Table 2. Regression Analysis.

\begin{tabular}{|c|c|c|c|c|}
\hline \multirow{4}{*}{ Explanatory variables } & \multirow{4}{*}{ Coefficients } & \multicolumn{3}{|c|}{ Pseudo $R^{2}=0.5090$} \\
\hline & & \multicolumn{3}{|c|}{ Marginal effects } \\
\hline & & $\delta E y$ & $\delta E y^{*}$ & $\delta F(z)$ \\
\hline & & $\overline{\delta X_{i}}$ & $\overline{\delta X_{i}}$ & $\overline{\delta X_{i}}$ \\
\hline Experience & $-0.007(0.005)$ & -0.005 & -0.003 & -0.006 \\
\hline Education & $0.007(0.010)$ & 0.005 & 0.003 & 0.005 \\
\hline Household size & $0.024 * *(0.012)$ & 0.016 & 0.009 & 0.019 \\
\hline Price of processed sunflower & $0.001 * * *(0.0001)$ & 0.001 & 0.0004 & 0.001 \\
\hline Distance to sunflower processing machines & $-0.045 * * *(0.012)$ & -0.030 & -0.017 & -0.036 \\
\hline Group-Membership $^{\wedge}$ & $0.136 * *(0.076)$ & 0.135 & 0.077 & 0.148 \\
\hline Sunflower Output $^{\mathrm{a}}$ & $0.145^{* * *}(0.043)$ & 0.097 & 0.056 & 0.115 \\
\hline Other income sources & $-0.032(0.110)$ & -0.021 & -0.012 & -0.026 \\
\hline Constant & $-1.121 * * *(0.305)$ & & & \\
\hline
\end{tabular}

The results show that the number of people in a household had a positive influence on the proportion of sunflower sold as seeds. This implies that the increase in the number of people in a household (family labor) by one person lead to an increase in the proportion of sunflower sold as seeds. This is because the higher household labor endowment enables to produce more and reduce the costs of transaction during processing.

The membership in a farmers' group was significantly higher proportion of sunflower sold as seeds because it enables easier access to processing services through transport-pooling. In this study, membership to sunflower farmers' groups was affected positively the proportion of sunflower sold as seeds. Distance to the nearest sunflower processing machines affected negatively the proportion of sunflower sold as seeds because households who are closer to processing services face lower transactions costs of processing sunflower and were more likely to process their crop before sale than those at residing more distant to the processing machines. This concurs with other findings [2025].

In Table 2, the elasticities in the Tobit Model were decomposed into three parts [26]. The marginal effects of unconditional expected value of the dependent variable are presented in the third column of the table. The marginal effects of the expected value of the dependent variable 
conditional on being uncensored or above zero are shown in the fourth column. The marginal effects of the probability of being above zero or uncensored are shown in the last column of the Table.

There was an increase the proportion of harvested sunflower sold by sunflower-growing households by $1.6 \%$ due to increase in the number of households' member by one person. The proportion of sunflower selling sunflower as seeds (for households selling processed sunflower) increased by $0.9 \%$ and increases the likelihood of selling sunflower by $1.9 \%$. Also one Tanzanian shillings increased the price of processed sunflower and increased the proportion of harvested sunflower sold by $0.1 \%$; increased the proportion of sunflower sold as sunflower seeds by $0.04 \%$ and increased the likelihood of making a sale by $0.1 \%$. The increase in distance by one kilometer to the sunflower processing machines reduces the proportion of sunflower sold by all sunflower-growing households by three percent; reduced the proportion of sunflower processed before sale (for households selling processed sunflower) by $1.7 \%$ and reduced the probability of making a sale by $3.6 \%$. Membership increased the proportion of harvested sunflower sold by $13.5 \%$; increased the proportion of sunflower sold as seeds by $7.7 \%$ and increased their probability of making a sale by $14.8 \%$. Finally, an increase of the harvested volume of sunflower by one kilogram, increased the proportion of harvested sunflower sold by $9.7 \%$; increased the proportion of sunflower sold as seeds by $5.6 \%$ and increased the likelihood of selling sunflower by $11.5 \%$.

\section{Conclusion}

Sunflower production was profitable venture regardless of the form in which the farmers choose to sell their products. It was even more profitable for the farmers who process sunflower before sale, thus it is important for the farmers being encouraged and assisted to process sunflower before sale through training at farm level and through interventions such as marketing collectively, access to yield-enhancing inputs and spreading of processing to larger volumes to reduce the process costs during processing. Marketing of sunflower though collective action was supported by the positive relationships between the proportion of sunflower sold as seeds and membership in farmers' groups and volume of sunflower harvested. The interventions that enable processing services to be brought closer to farmers in major sunflower growing areas in Tanzania will reduce the transactions costs of accessing processing services and encourage sunflower processing before sale it was supported by the negative relationship between the proportion of sunflower sold as seeds and distance to the nearest sunflower processing machines in this study. Facilitating the private entrepreneurs to set up processing plants closer to farmers through rural electrification and reduction of electricity tariffs or improving the rural road network to facilitate private investments in mobile sunflower processing machines are other possible areas of intervention suggested in this study.

\section{References}

[1] FAOSTAT (2015). Production of Sunflower Seeds in Tanzania. [www.faostat.org] visited on 12/08/2017. Iringo, R. (2017). Sunflower Subsector. Collaboration between Sunflower Oil Processors and RLDC for Improved Sunflower Sector in Tanzania. A Power Point presentation. 12 pp.

[2] United Republic of Tanzania (URT) (2016). Sunflower Sector Development Strategy: 2016-2020.

[3] Match Maker Associates Limited (2016). Value Chain Analysis of Sunflower for the Regions of Ahuja, V., Deininger, U. D., and Haan, D. C. (2003). Market structure and the demand for veterinary services in India, Agricultural Economics 29 (2003) 27-42.

[4] TEOSA (2012). Assessment of the Potential of Edible Oilseeds Produced in Tanzania: The Case of the Sunflower and Sesame. [www.best-dialogue.org] visited on 25/08/2016.

[5] Match Maker Associates Limited (2015). Mapping Exercise for Food Processing and Marketing SMEs in Tanzania. A Report for Commissioned by SME Competitiveness Facility (SCF). 63 pp.

[6] USDA, 2016. Agricultural Marketing Service - Cotton and Tobacco Program, Cotton Varieties Planted 2014 Crop Report, Memphis, TN, $10 \mathrm{pp}$.

[7] Malk, M. A. and Sain, C. S. (2016). Engineering Properties of Sunflower Seed. Effects of Dehullling and Moisture Content. Cogent Food and Agriculture 3 (2): 1-11.

[8] Iringo, R. (2013). Sunflower Subsector. Collaboration between Sunflower Oil Processors and RLDC for Improved Sunflower Sector in Tanzania. A Power Point presentation. 12 pp.

[9] Salisali, B. M. (2015). Brief on Project Implementation Sunflower Sector. A Report for Rural Livelihood Development Programme (RLDP). 9 pp.

[10] Amin, M. E. (2013). Overview of the methodology of research. A paper presented at a seminar on overview of Educational Research Methodology for teachers of the School of Education, Makerere University, Kampala.

[11] Bao Thoa, H. T. (2016). The value chain management of garment companies in Vietnam. The University of the Thai Chamber of Commerce. Thailand.

[12] Castle, N. E., Manning, H. B., and Gene, A. N. (2017). Farm business management; Decision making process (3rd Ed) Macmillan publishing company, New York.

[13] Jamala, Y. G., Shehu, E. H., Apollos, T., and Garba, T. A. (2011). Evaluation of factors influencing farmers adoption of irrigated rice production in Fadama soil of North Eastern Nigeria. Journal of Development and Agricultural Economics Vol. 3 (2), 75-79.

[14] Astewel, T. (2016). Analysis of rice profitability and marketing chain: The case of Fogera Woreda, South Gondar zone, Amhara National Regional State, Ethiopia. Published Msc thesis of Hamaraya University, Ethiopia.

[15] Sserunkuuma, D. (2015). Assessment of NERICA Training Impact: A Study Report Prepared for the Japan International Cooperation Agency (JICA). 
[16] Elepu, G., and Nalukenge, I. (2009). Contract Farming, Smallholders and Commercialization of Agriculture in Uganda: The Case of Sorghum, Sunflower, and Rice Contract Farming Schemes. Agriculture for Development, Center of Evaluation for Global Action, UC Berkeley, [http://escholarship.org/uc/item/97g2r7mk] site visited on 21/06/2017.

[17] Banta, A. L., Kudi, T. M., and Ghartey, W. (2008). Analysis of profitability of transplanted rice in Fadamas of Zango Kataf Local government area of Kaduna state, Nigeria, Journal of Agriculture, Forestry and the Social Sciences, Vol 6 No 2 (ISSN: 1597-0906).

[18] Manus, P. A., and Halim, A. (2010). Profitability of smallholder rice production in selected Agro-ecological zones of Papua New Guinea. Niugini Agrisaiens Vol 2 (1), 9-16.

[19] Bellemare, F. M., and Barrett, B. C. (2014). An Ordered Tobit: Model of Market Evidence from Kenya and Ethiopia.

[20] Komarek, A. (2010). The determinants of banana market commercialization in Western Uganda. African Journal of Agricultural Research Vol. 5 (9), pp. 775-784. Morogoro, Iringa, Mbeya and Rukwa. A study for ACT-Tanzania Agricultural Partnership. 17 pp.

[21] Otieno, J. D., Omiti, J., Nyanamba, T., and McCullough, E.
(2009). Market participation by vegetable farmers in Kenya: A comparison of rural and peri-urban areas. African Journal of Agricultural Research Vol. 4 (5), 451-460.

[22] Ahuja, V., Deininger, U. D., and Haan, D. C. 2003. Market structure and the demand for veterinary services in India, Agricultural Economics 29 (2003) 27-42.

[23] Mukama, E. (2017). Market participation among Banana farmers in Central Uganda, Unpublished Msc thesis, Department of Agribusiness and Natural Resource Economics, College of Agricultural and Natural Resource Sciences, Makerere University Kampala.

[24] Rios, R. A., Masters, A. W., and Shively, E. G. (2017). Farm Productivity and Household Market Participation: Evidence from LSMS Data. Paper prepared for presentation at the $27^{\text {th }}$ International Conference of Agricultural Economists, Beijing, China.

[25] Wakulira, M. (2016). Factors influencing hulling of coffee among farmers in Masaka District, Uganda; Unpublished Msc thesis, Department of Agribusiness and Natural Resource Economics College of Agricultural and Natural Resource Sciences, Makerere University Kampala.

[26] McDonald, J. F., and Moffitt, R. A. (1980). The uses of Tobit analysis, the review of Economics and statistics 62, 2: 318-321. 